\title{
OPEN Author Correction: TRAF3 regulates the oncogenic proteins Pim2 and c-Myc to restrain survival in normal and malignant $B$ cells
}

\author{
Amy L. Whillock, Nurbek Mambetsariev, Wai W. Lin, Laura L. Stunz \& Gail A. Bishop \\ Correction to: Scientific Reports https://doi.org/10.1038/s41598-019-49390-9, published online 09 September \\ 2019
}

This Article contains errors in the Introduction.

“TRAF3-deficient B cells were more susceptible to biochemical Pim2 inhibition and more resistant to inhibitors of the phosphatidyl inositol-3 kinase/protein kinase B (PI3K/Akt) pathway compared to wild type (WT) B cells. Low TRAF3 expression in human BCL and MM cell lines correlated with higher Pim2 protein levels and decreased susceptibility to Pim2 inhibitor-mediated cell death."

should read:

"TRAF3-deficient B cells were less susceptible to biochemical Pim2 inhibition compared to wild type (WT) B cells. Low TRAF3 expression in human BCL and MM cell lines correlated with higher Pim2 protein levels and increased susceptibility to Pim2 inhibitor-mediated cell death."

(c) Open Access This article is licensed under a Creative Commons Attribution 4.0 International License, which permits use, sharing, adaptation, distribution and reproduction in any medium or format, as long as you give appropriate credit to the original author(s) and the source, provide a link to the Creative Commons license, and indicate if changes were made. The images or other third party material in this article are included in the article's Creative Commons license, unless indicated otherwise in a credit line to the material. If material is not included in the article's Creative Commons license and your intended use is not permitted by statutory regulation or exceeds the permitted use, you will need to obtain permission directly from the copyright holder. To view a copy of this license, visit http://creativecommons.org/licenses/by/4.0/.

(C) The Author(s) 2019 